\title{
Slow population turnover in the soft coral genera Sinularia and Sarcophyton on mid- and outer-shelf reefs of the Great Barrier Reef
}

\author{
Katharina E. Fabricius* \\ Australian Institute of Marine Science, PMB 3, Townsville, Queensland 4810, Australia
}

\begin{abstract}
Aspects of the life history of the 2 common soft coral genera Sinularia and Sarcophyton were investigated on 360 individually tagged colonies over $3.5 \mathrm{yr}$. Measurements included rates of growth, colony fission, mortality, sublethal predation and algae infection, and were carried out at 18 sites on 6 mid-and outer-shelf reefs of the Australian Great Barrier Reef. In both Sinularia and Sarcophyton, average radial growth was around $0.5 \mathrm{~cm} \mathrm{yr}^{-1}$, and relative growth rates were size-dependent. In Sinularia, populations changed very slowly over time. Their per capita mortality was low $\left(0.014 \mathrm{yr}^{-1}\right)$ and size-independent, and indicated longevity of the colonies. Colonies with extensions of up to $10 x$ $10 \mathrm{~m}$ potentially could be several hundreds of years old. Mortality was more than compensated for by asexual reproduction through colony fission $\left(0.035 \mathrm{yr}^{-1}\right)$. In Sarcophyton, mortality was low in colonies larger than $5 \mathrm{~cm}$ disk diameter $\left(0.064 \mathrm{yr}^{-1}\right)$, and significantly higher in newly recruited small colonies $\left(0.88 \mathrm{yr}^{-1}\right)$. Photographic monitoring of about 500 additional colonies from 16 soft coral genera showed that rates of mortality and recruitment in the family Alcyoniidae differed fundamentally from those of the commonly more 'fugitive' families Xeniidae and Nephtheidae. Rates of recruitment by larval settlement were very low in a majority of the soft coral taxa. The general assumption that soft corals are fast-growing pioneers does not apply to the Alcyoniidae on the central Great Barrier Reef, where their life history traits indicate great persistence.
\end{abstract}

KEY WORDS: Octocorallia A Alcyoniidae S Sinularia Sarcophyton - Life history traits - Growth - Mortality $\cdot$ Recruitment

\section{INTRODUCTION}

The octocoral fauna of Indo-Pacific reefs is dominated by the 3 soft coral families Xeniidae, Nephtheidae and Alcyoniidae (Bayer 1957). Previous demographic investigations of reef-inhabiting xeniid and nephtheid taxa led to the generalization that soft corals are ephemeral pioneer organisms, with rapid growth rates, high rates of vegetative reproduction, the ability to form runners, and whole-colony movement. For example, high rates of asexual reproduction were found in the xeniid Efflatounaria (Dinesen 1985) and the Red Sea xeniid Xenia macrospiculata (Benayahu \& Loya 1984). The nephtheid Litophyton viridis shows high growth rates, the ability to re-attach dislodged

\footnotetext{
•E-mail:k.fabricius@aims.gov.au
}

colonies, and asexual propagation by runner formation (Tursch \& Tursch 1982). High potential for asexual propagation, fast growth and high predation rates characterize the nephtheid Dendronephthya hemprichi from the Red Sea (Fabricius et al. 1995). X macrospiculata and the arborescent Nephthea brassica can move very slowly over the substrate, by means of directional growth at the leading edge of the colony stem and tissue resorption from the trailing edge (Benayahu \& Loya 1981, La Barre \& Coll 1982).

No studies so far have quantified life history traits of tropical members in the third family, the Alcyoniidae, in spite of the family's high abundances in a wide range of reef types (Dinesen 1983). Habitats of Alcyoniidae include wave-exposed areas of reef crests on the windward sides, flow-protected regions in lagoons, and zones of low irradiance on steep slopes, overhangs 
and below $30 \mathrm{~m}$ depth (K. Fabricius unpubl.). In the present study, life history parameters of the 2 most common alcyoniid genera, Sinularia and Sarcophyton, were investigated on clear-water reefs 60 to $80 \mathrm{~km}$ off the east Australian coast. To date, 110 Sinularia and 36 Sarcophyton species have been described from the Indo-Pacific (reviews by Verseveldt 1980, 1982). However, a great number of species are as yet undescribed, and field identification of most species is impossible. An investigation of genera, rather than species, is justifiable given the current taxonomic uncertainties.

Sinularia colonies form mats several centimeters thick whose surfaces are structured by protruding lobes or ridges. Large sclerites are densely packed in the colony, and only 1 polyp type exists. Sarcophyton colonies are distinctly mushroom-shaped, with a thick fleshy stem elevating the polyp-bearing marginally folded colony disk (capitulum) off the substratum. The colonies are dimorphic, i.e. they possess 2 polyp types: the autozooids or feeding polyps, and embedded between those, the tentacle-free and sterile siphonozooids. Both taxa are light-dependent due to their symbiotic zooxanthellae.

Sinularia and Sarcophyton are both abundant on the central Great Barrier Reef. A survey on 14 mid-and outer-shelf reefs showed that Sinularia contributed on average 20 to $42 \%$ to the total soft coral cover $(1.7 \% \pm$ 2.4 SD cover of hard substratum) at 5 to $30 \mathrm{~m}$ depth. Sarcophyton accounted for $7.0 \% \pm 6.5 \mathrm{SD}$ of soft coral cover $(0.4 \% \pm 0.7 \mathrm{SD}$ of hard substratum) in the upper $15 \mathrm{~m}$ of water. Its proportion in total soft coral cover increased to $55 \%$ at $30 \mathrm{~m}$ depth (K. Fabricius unpubl.). The present study investigates life history characteristics which allow these genera to achieve such prominence. An understanding of their demographic traits is also relevant to the assessment of the effects of anthropogenic influences and natural forces in coral reefs, and to refine mechanistic models of succession after reef disturbances (Pearson 1981). The present study demonstrates life history traits in 2 common alcyoniid genera which contrast strongly to those described for any other reef-inhabiting soft coral taxon

\section{METHODS}

Study sites. Three monitoring sites were established at $10 \mathrm{~m}$ depth on the windward sides of each of 6 midand outer-shelf reefs. The reefs represented a range of different habitat types within the region, with varying degrees of hard and soft coral cover, current and wave exposure, and slope angle (Table 1). Bowl, Dip and Coil Reef are located on the outer edge of the continental shelf and are exposed to strong currents and wave action, whereas the positions of Grub. Centipede and Yankee Reefs provide more protection from these physical forces. High numbers of crown-of-thorns starfish (Acanthaster planci) removed most of the hard coral cover on 3 of the reefs 5 to 8 yr prior to the commencement of the study (Grub, Yankee and Dip). The other 3 reefs (Centipede, Bowl and Coil) were affected very little, if at all, by these coral-eating starfish (Bass et al. 1988) and hard coral cover was significantly higher than on the disturbed reefs in 1991 (K. Fabricius unpubl.). A direct comparison of life history traits between sites was not attempted, since each site may have had a unique species composition. The distance between the 3 sites on each reef was 500 to $2000 \mathrm{~m}$. Because of their wave exposure, 4 of the sites were inaccessible at later resurvey attempts (2 at Bowl, 1 at Yankee, 1 at Centipede Reef), and were excluded from the data set. Some colonies were lost due to overgrowth of tags used for labeling.

Field measurements. The first 10 Sinularia and 10 Sarcophyton colonies encountered, regardless of size, were at each site permanently marked with small, numbered PVC tags which were nailed or tied onto the adjacent substrate. The distance between closest neighbours of tagged colonies ranged from 0.5 to $10 \mathrm{~m}$. The initial 360 colonies were surveyed 7 times over 41 mo between February 1991 and July 1994.

Colony size was determined as longest and shortest colony disk diameter, and stem or colony circumference, using calipers and measurement tapes. Repeated size determinations on 30 colonies in expanded and

Table 1 . Characteristics of the 6 study reefs ( 3 sites per reef). Wave exposure according to the location on the continental shelf; average \% cover on the windward side at $10 \mathrm{~m}$ depth of hard and soft corals (based on two $25 \mathrm{~m}$ long line transects at each site); COT: records of recent crown-of-thorns starfish outbreaks; slope angle on the 3 study sites

\begin{tabular}{|lccccc|}
\hline Reef & Wave exposure & $\begin{array}{c}\text { Hard coral cover } \\
(\% \pm \text { SD })\end{array}$ & $\begin{array}{c}\text { Soft coral cover } \\
(\% \pm \text { SD })\end{array}$ & CoT outbreaks & Slope \\
\hline Bowl & High (outer-shelf) & $44.4 \pm 12.8$ & $1.0 .6 \pm 4.4$ & No & Gradual $\left(15^{\prime \prime}\right)$ \\
Corl & High (outer-shelf) & $43.9 \pm 16.5$ & $8.6 \pm 2.4$ & No & Steep $\left(60-80^{\circ}\right)$ \\
Dip & High (outer-shelf) & $19.2 \pm 8.4$ & $14.1 \pm 5.7$ & Yes $(1983-1985)$ & Steep $\left(50-80^{\circ}\right)$ \\
Yankee & Medium (mid-/outer-shelf) & $23.3 \pm 8.1$ & $12.2 \pm 4.7$ & Yes $(1984-1987)$ & Various $\left(20^{\circ}, 80^{\circ}\right)$ \\
Centipede & Moderate (mid-shelf) & $44.1 \pm 8.0$ & $5.6 \pm 3.0$ & No/low & Various $\left(40^{\circ}, 40^{\circ}, 70^{\circ}\right)$ \\
Grub & Moderate (mid-shelf) & $27.8 \pm 20.9$ & $7.5 \pm 3.1$ & Yes $(1985-1986)$ & Various $\left(40^{\circ}, 40^{\circ}, 80^{\circ}\right)$ \\
\hline
\end{tabular}


contracted state $(5 \mathrm{~min}$ after firmly touching the colony), plus an interval between the first and second survey of only 6 wk, were used to estimate the error due to colony contraction. This indicated that contraction reduced the colony diameter on average by $9 \% \pm$ 1.3 SE in healthy Sinularia colonies, and $12 \% \pm 1.9 \mathrm{SE}$ in Sarcophyton. Sinularia infected with epiphytic algae were always firmly contracted. They measured around $80 \%$ of the diameter when last observed in the healthy, contracted state. All measured values were converted to the size of healthy contracted colonies $\left(S_{C}\right)$ according to the equations: for Sinularia, $S_{\mathrm{C}}=0.91 \times$ expanded size, or $1.2 \times$ algae covered size; for Sarcophyton, $S_{C}=0.88 \times$ expanded size. The state of expansion and contraction, signs of recent predation and old bite marks, algae overgrowth and stage of colony fission were recorded during each survey. Initial colony sizes were plotted against final sizes as in Sebens (1984). Life history events of individual colonies were plotted over time by modifying the event charts of Goldman (1992).

Colony shape, and the type and distance of biotic neighbours were recorded stereophotographically during the second (April 1991) and the last surveys (July 1994). The 226 pairs of photographs were also analyzed to monitor the position, longevity and turnover rates of around 500 soft coral colonies growing on the substrate around the labelled colonies. The stereo rig was positioned using the colony tag as center and indicator for the orientation of the photographed rectangle. A total area of around $100 \mathrm{~m}^{2}$ of reef substrate was analyzed in this manner. Each photograph covered an area of $0.8 \times 1.2 \mathrm{~m}$, but in order to allow for colony movement and inaccurate repositioning of the stereo rig (Done 1981), the outer $15 \mathrm{~cm}$ edges were not included in the analysis. It is possible that some colonies may have moved further than this; therefore the category 'disappeared' includes dead and emigrated colonies, and the category 'appeared new' may consist of some immigrated colonies besides the newly recruited ones. Growth rates in colonies other than
Sinularia and Sarcophyton could not be assessed with the photographs, because the extent of size reduction during colony contraction was not known.

In a pilot study on relative recruitment success in soft coral taxa, 180 settlement plates $(10 \times 15 \mathrm{~cm}, 2 \mathrm{~cm}$ thick) cut out of Porites skeleton were tied in lots of 10 onto sheets of construction steel mesh, and deployed at 3 sites in 5,10 and $15 \mathrm{~m}$ water depth each at Grub and Centipede Reefs (2 reefs, 3 sites, 3 depths, sets of 10 plates). The plates on the steel mesh were set up face-down $20 \mathrm{~cm}$ above the substrate, and left in place for 12 mo (from August 1991). After their retrieval, the upper and lower surface and the edges of the plates were examined immediately for recruiting colonies under a dissecting microscope.

\section{RESULTS}

The study showed very slow colony growth and population turnover rates in Sinularia, and slightly faster growth, recruitment and mortality processes in Sarcophyton. Of the 360 colonies which were initially tagged, 226 were surveyed over the $3.5 \mathrm{yr}$ period, while the others died or were lost. The variability in the measured parameters over time and between the colonies was lower in Sinularia than in Sarcophyton.

\section{Growth rates}

In Sinularia, colony sizes changed only a little over 3.5 yr (Fig. 1a). The linear correlation between initial and final colony diameter was very high $\left(R^{2}=0.90\right)$, and the slope of the regression line $(0.93 \pm 0.035 \mathrm{SE})$ deviated little from the diagonal of zero-growth. The diameter of Sinularia colonies increased on average $0.5 \mathrm{~cm} \mathrm{rr}^{-1} \pm 0.2 \mathrm{SE}$, but many shrank or grew faster than this. Relative rates of growth decreased with increasing size from a mean of around $20 \% \mathrm{yr}^{-1}$ in colonies $<5 \mathrm{~cm}$ to $2 \% \mathrm{yr}^{-1}$ in colonies $>20 \mathrm{~cm}$ diameter

Table 2. Growth rates in Sinularia and Sarcophyton. Size is given as the mean between the longest and shortest colony diameter. Growth rates are changes in colony diameter between 2 consecutive measurements, extrapolated to yearly rates. N: number of observations

\begin{tabular}{|c|c|c|c|c|c|c|}
\hline \multirow{2}{*}{$\begin{array}{l}\text { Initial size } \\
\text { class (cm) }\end{array}$} & \multicolumn{3}{|c|}{ Sinularia } & \multicolumn{3}{|c|}{ Sarcophyton } \\
\hline & $\begin{array}{l}\text { Linear growth } \\
\left(\mathrm{cm} \mathrm{yr}^{-1} \pm \mathrm{SE}\right)\end{array}$ & $\begin{array}{l}\text { Rel growth } \\
\left(\% \mathrm{yr}^{-1} \pm \mathrm{SE}\right)\end{array}$ & $N$ & $\begin{array}{l}\text { Linear growth } \\
\left(\mathrm{cm} \mathrm{yr}^{-1} \pm \mathrm{SE}\right)\end{array}$ & $\begin{array}{l}\text { Rel. growth } \\
\left(\% \mathrm{yr}^{-1} \pm \mathrm{SE}\right)\end{array}$ & $N$ \\
\hline $0.5-4.9$ & $1.4 \pm 0.5$ & $19.6 \pm 5.6$ & 64 & $1.0 \pm 0.4$ & $27.7 \pm 2.4$ & 64 \\
\hline $5-9.9$ & $1.0 \pm 0.3$ & $10.6 \pm 1.3$ & 181 & $1.0 \pm 0.5$ & $16.3 \pm 1.5$ & 109 \\
\hline $10-14.9$ & $1.2 \pm 0.4$ & $9.5 \pm 0.7$ & 159 & $1.4 \pm 0.6$ & $11.6 \pm 1.5$ & 105 \\
\hline $15-19.9$ & $0.6 \pm 0.5$ & $6.4 \pm 0.9$ & 128 & $0.4 \pm 0.8$ & $7.6 \pm 1.4$ & 97 \\
\hline$\geq 20$ & $-1.5 \pm 0.8$ & $2.3 \pm 2.0$ & 112 & $-0.7 \pm 1.0$ & $6.1 \pm 1.7$ & 97 \\
\hline
\end{tabular}




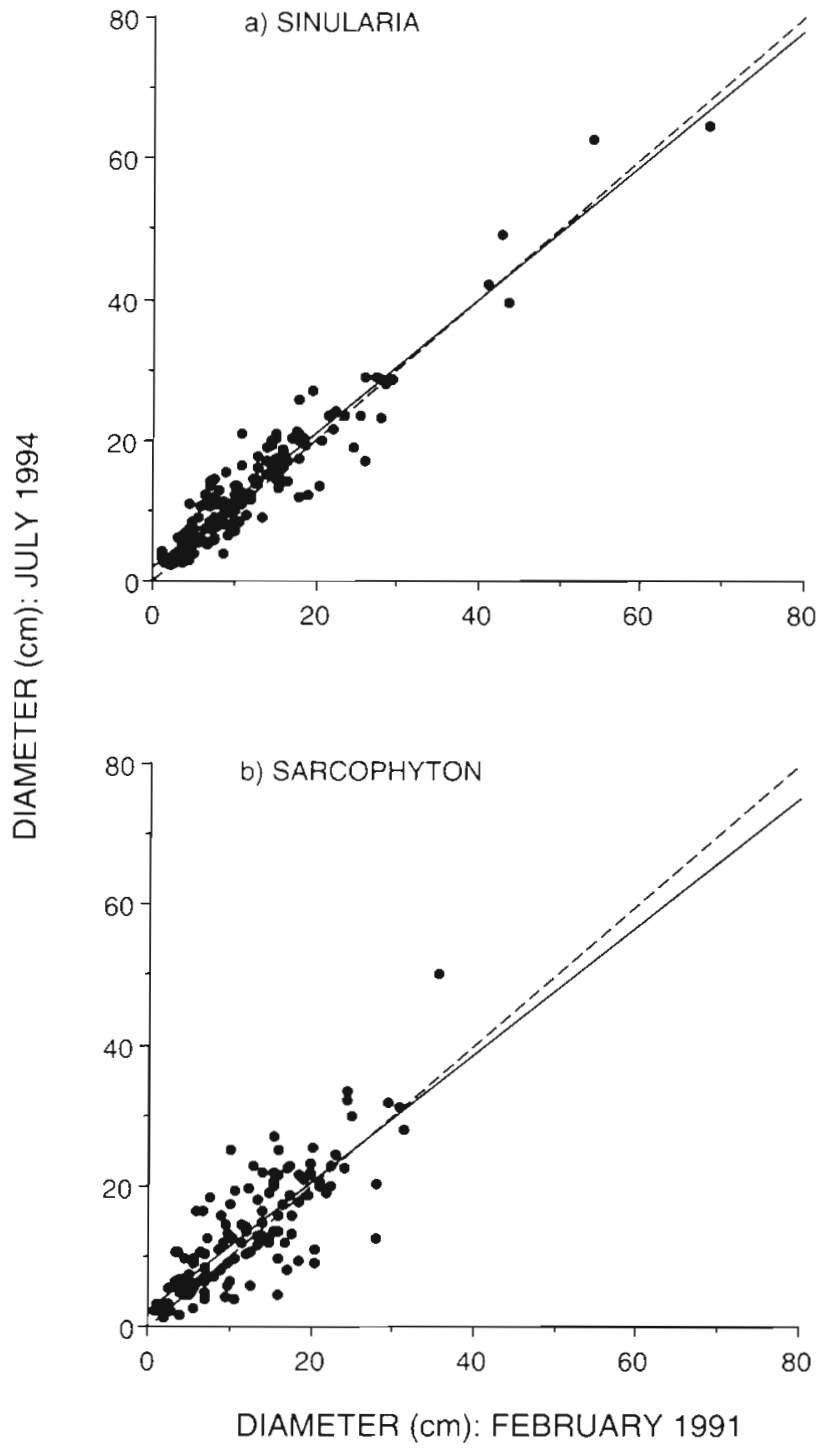

Fig. 1. Change in colony size over 3.5 yr: plot of colony diameter in February 1991 versus July 1994. Solid lines are calculated by linear regression, dashed lines: no change. (a) Sinularia: diameter $1994=1.80+0.93 \times$ diameter 1991, SE of slope $=0.04, \mathrm{R}^{2}=0.903$. (b) Sarcophyton: size $1994=2.16+$ $0.95 \times$ size $1991, \mathrm{SE}$ of slope $=0.07, \mathrm{R}^{2}=0.652$

(Table 2). The diameter of Sinularia colonies encountered during a community survey averaged $13.3 \mathrm{~cm}$ $(\mathrm{N}=1117$ colonies in 84 transects of $25 \times 0.5 \mathrm{~m}$ each). Colony shrinkage was particularly common after periods of infection with epiphytic algae. Colony biomass. measured as ash-free dry weight (AFDW) was strongly related to the colony area, in spite of the mixed species composition of the sample (linear correlation analysis, $0.058 \mathrm{~g} \mathrm{AFDW} \mathrm{cm}^{-2}$ colony area, SE of coeff. $=0.0046$ $\mathrm{R}^{2}=0.90, \mathrm{~N}=23$ colonies). The amount of organic biomass in relation to the total colony dry weight was low
$(10.4 \% \pm 0.8 \mathrm{SE})$, due to the densely packed sclerites (calcareous spiculae) in the tissue.

In Sarcophyton, relative growth rates also decreased with increasing colony diameter, from $28 \% \mathrm{yr}^{-1}$ in very small colonies to $6 \%$ in large colonies (Fig. 1b, Table 2). Average colony diameter in the community survey was $11.3 \mathrm{~cm}(\mathrm{~N}=598$ colonies $)$. Radial growth of colonies which were undamaged and not preyed upon averaged $0.6 \mathrm{~cm} \mathrm{yr}^{-1} \pm 0.3 \mathrm{SE}$. The proportion of growing colonies averaged $55 \%$ in colonies $<5 \mathrm{~cm}$ initial diameter, and 43 to $44 \%$ in the other size classes. Reduction of colony size was mostly found on colonies with signs of predation. In spite of the erect shape and a higher proportion of organic tissue in colony dry mass in Sarcophyton $(28.9 \% \pm 1.7 \mathrm{SE})$, the biomass $\mathrm{cm}^{-2}$ colony area was $31 \%$ lower in this genus than in the flat Sinularia $\left(0.04 \mathrm{~g}\right.$ AFDW $\mathrm{cm}^{-2}$, SE of coeff. = $0.0039, \mathrm{R}^{2}=0.79, \mathrm{~N}=29$ colonies).

\section{Mortality, predation and asexual reproduction}

Rates of reproduction and mortality, predation and infection with epiphytic algae varied between taxa. In Sinularia, the population was very stable (Fig 2a). Most colonies lived through the whole survey period without reproducing asexually, and without obvious predator damage, and only a few colonies disappeared, or appeared for the first time. Asexual offspring were produced by $3.5 \%$ of the colonies $\mathrm{yr}^{-1}$ (Table 3). The mode of asexual reproduction was colony fission, resulting in 2 (rarely more) closely adjacent colonies of the same height which did not move apart from each other. Fission seemed to occur mostly as a consequence of colony injury. The rate of spontaneous or induced colony fission was so low that the life history traits approximated those of an aclonal organism. A small number of colonies disappeared $(1.4 \%$ $\left.\mathrm{yr}^{-1}\right)$, but due to the small number of observations, no relationship between colony size and mortality was

Table 3. Life history events in Sinularid and Sarcophyton. Rates of mortality and reproduction as $\mathrm{yr}$ Number of observed colonies: 182 in Sinularia, and 167 in Sarcophyton. Rates of algae infection and predation damage as percent colonies at any point in time. Number of observations: 702 in Sinularid, and 614 in Sarcophyton. Variation between the observation periods given as $1 \mathrm{SD}$

\begin{tabular}{|lrc}
\hline & Sinulana & Sarcophyton \\
\hline Mortality & $1.4 \pm 1.5$ & $17.1 \pm 11.0$ \\
Colony fission/budding & $3.5 \pm 3.5$ & $8.8 \pm 8.7$ \\
Algae infection & $11.4 \pm 2.1$ & $0.1 \pm 0.3$ \\
Predation damage & $4.1 \pm 1.2$ & $5.3 \pm 3.7$ \\
\hline
\end{tabular}



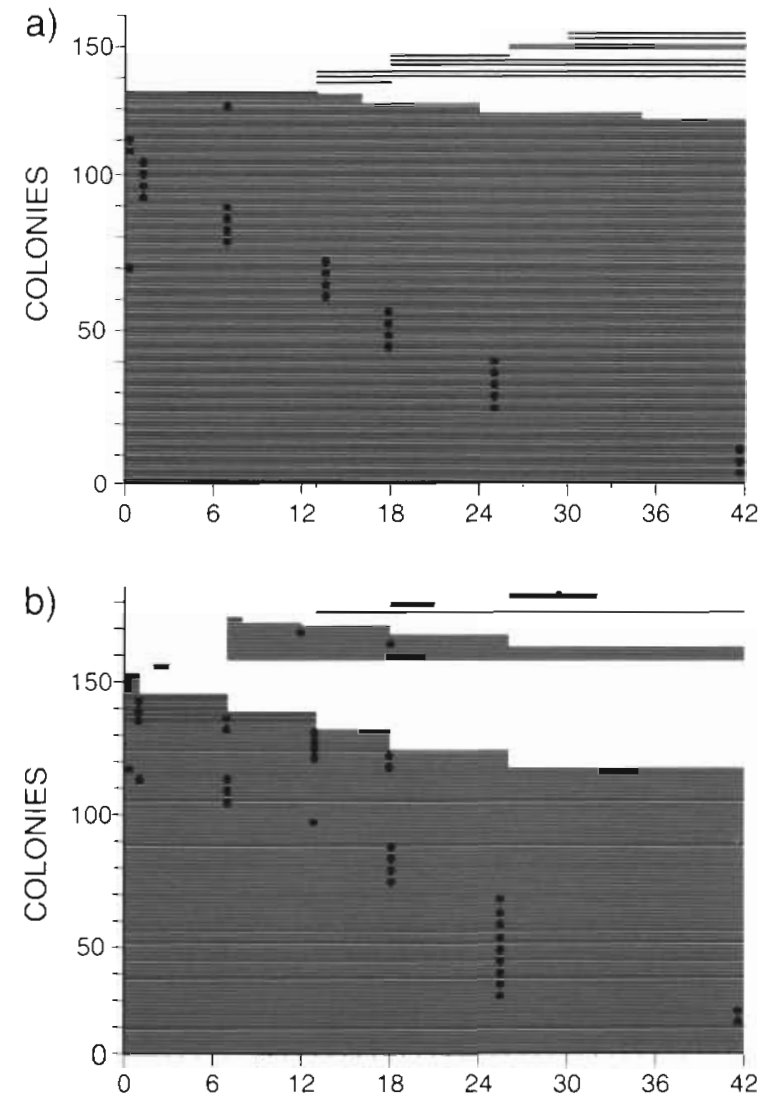

MONTHS

Fig. 2. Event chart of (a) Sinularia and (b) Sarcophyton. Each bar represents an individually tagged colony. Bars ending before Month 42 depict colony death, those beyinning later than at point zero represent new recruits or propagules. Filled circles indicate predation events. The great majority of the colonies lived through the whole survey period. Note the high number of Sarcophyton recruits at Month 7 (August 1991)

apparent. Overgrowth by epiphytic algae was common, but showed no obvious detrimental long-term effects. Predation upon Sinularia was mostly restricted to the tips of the lobes, only occasionally caused size reduction, and never led to colony death.

Mean rates of reproduction, mortality and predation in Sarcophyton seemed slightly higher than in Sinularia. Overgrowth with epiphytic algae was uncommon (Fig. 2b, Table 3). Offspring of Sarcophyton often appeared to settle within $20 \mathrm{~cm}$ distance from a colony, or budded off from the stem base or disk of the mother colony. Stolons connecting a colony and nearby recruits on the substrate were not observed (except in Sarcophyton tortuosum, see below), indicating that these new colonies may have been either produced by larvae which tend to settle in close proximity to the mother colony, or by buds dropped off the mother colony. Thus offspring were probably produced both sexually and asexually. Generally, 2.5 to $3.5 \%$ of colonies larger than $3 \mathrm{~cm}$ had offspring in their vicinity each year However this rate was much higher in August 1991 (27\% $\mathrm{yr}^{-1}$, Fig. 2b). Mortality of the newly produced offspring was high $(88 \%)$, whereas in the parent colonies it was low $\left(6.4 \% \mathrm{yr}^{-1}\right)$. Predation accounted for $69 \%$ of mortality of known cause, with the balance due to substrate dislodgement. On average, $5.3 \% \pm 3.7 \mathrm{SD}$ of Sarcophyton colonies showed new or almost healed predation scars at any time. Depending on the extent of damage, the scars disappeared within 3 to $6 \mathrm{mo}$. In 9 instances, the whole colony disk was eaten. Colonies which were damaged by predators or by partial burial under rubble started growing a new disk, or they produced several daughter colonies before dying. Either response ensured survival of the genet.

\section{Interactions with other organisms}

In Sinularia, $44.5 \%$ of the 182 colonies contacted neighbouring biota with at least a small proportion of the colony margin. None of the monitored Sinularia colonies were competitively inferior to any other species, whereas in 3 cases, Sinularia overgrew and killed a neighbouring scleractinian coral. In all other cases, the growth of both Sinularia and neighbours in the contact zone seemed to have stopped, and neither competitor showed tissue damage during the survey period.

In Sarcophyton, $21.8 \%$ of the colonies contacted other macrobenthos. Five instances of obvious interactions were observed. On 1 occasion, a sponge gradually smothered a small Sarcophyton colony over $18 \mathrm{mo}$, while Sarcophyton overgrew their scleractinian neighbour in 4 instances. The other 23 cases of direct contact resulted in no signs of detrimental impact. Rather, the neighbouring organism grew around the Sarcophyton stems, leaving a space of 0 to $2 \mathrm{~cm}$ in between.

In neither taxon were growth, reproduction or mortality influenced by contact with neighbours, or by overall space availability ( $t$-tests, $p>0.05$ in each case). This was true both in Acanthaster-affected and undisturbed areas

\section{Turnover rates of other soft coral taxa}

A total of 269 colonies and 34 clusters of colonies of various taxa were recorded once or twice in photographs of the substrate around the labelled colonies. The proportion of colonies which disappeared, or had recently settled, compared to those which remained 
over 3.5 yr, showed clear differences between families, in spite of low sample numbers in some taxa (Table 4). Turnover rates of xeniid and nephtheid colonies were 40 to $80 \%$. Similar rates were found for genera in uncommon families, such as Asterospicularia, Briareum and Clavularia. In contrast, the turnover rates of the commonly encountered genera of Alcyoniidae were only 0 to $20 \%$. All Sinularia and Sarcophyton colonies in the neighbourhood of the tagged colonies remained in place, and no new colonies had settled. The same was true for the almost equally common encrusting genus Lobophytum. The alcyoniid Cladiella was infrequent in the area, and 4 out of 5 colonies in the photographs occurred both in 1991 and in 1994

\section{Settlement plates}

On 5 of the 180 Porites settlement plates exposed in the preliminary recruitment study, a total of only 9 soft coral colonies had settled after 12 mo of exposure. All were Efflatounaria (Xeniidae) colonies with 3 to 8 polyps. They grew on the undersurface close to the edge of the plates from Centipede and Grub Reef sites in $15 \mathrm{~m}$ water depth. In contrast, approximately 1450 scleractinian coral colonies larger than $2 \mathrm{~mm}$ were found on the plates, some of which had grown to $1.5 \mathrm{~cm}$ in diameter.

\section{DISCUSSION}

Low rates of growth, reproduction and mortality characterize 2 alcyoniid soft coral genera on mid-and outer-shelf reefs. The variability in these parameters was small in Sinularia, in spite of the inclusion of an unknown number of species. Growth and biomass data of Sarcophyton were more variable, and investigations on individual species would reveal how much was due to interspecies variation. There are probably some species in both genera which are more opportunistic and short-lived, but these were obviously the minority in terms of colony numbers and percentage cover. One example of a more opportunistic species was Sarcophyton tortuosum (Tixier-Durivault 1946), a distinctly coloured and shaped species, which was uncommon

Table 4. Turnover rates in soft corals over 40 mo (March-April 1991 to July 1994) based on 226 pairs of photographs covering an area of around $100 \mathrm{~m}^{2}$ in total. Indicated are the proportion of colonies and colony groups which remained (R), disappeared (D) or appeared new (A) within this period. 'Colony groups' are clusters of colonies in which the fate of individual colonies could not be followed up because of high colony density or colony movement. $N$ : total number of colonies or colony groups observed

\begin{tabular}{|c|c|c|c|c|c|c|c|c|}
\hline \multirow[t]{2}{*}{ Taxon } & \multicolumn{4}{|c|}{ Colonies } & \multicolumn{4}{|c|}{ Colony groups } \\
\hline & $N$ & $\mathrm{R}$ & D & A & $N$ & $\mathrm{R}$ & $\mathrm{D}$ & $\mathrm{A}$ \\
\hline \multicolumn{9}{|l|}{ Xeniidae } \\
\hline Efflatounaria & 28 & 28.6 & 21.4 & 50 & 20 & 85 & 0 & 15 \\
\hline Xenia & 84 & 23.8 & 34.5 & 41.7 & 11 & 27.3 & 18.2 & 54.5 \\
\hline \multicolumn{9}{|l|}{ Nephtheidae } \\
\hline Nephthea & 14 & 28.6 & 50 & 21.4 & 1 & 100 & 0 & 0 \\
\hline Dendronephthya & 5 & 20 & 60 & 20 & 0 & - & - & - \\
\hline Stereonephthya & 2 & 100 & 0 & 0 & 0 & - & - & - \\
\hline Lemnalia & 4 & 50 & 0 & 50 & & & & \\
\hline Paralemnalia & 40 & 30 & 30 & 40 & 2 & 100 & 0 & 0 \\
\hline Capnella & 5 & 60 & 0 & 40 & 0 & - & - & - \\
\hline \multicolumn{9}{|l|}{ Alcyoniidae } \\
\hline Sarcophyton & 13 & 100 & 0 & 0 & 0 & - & - & - \\
\hline Sinularia & 9 & 100 & 0 & 0 & 0 & - & - & - \\
\hline Lobophytum & 7 & 100 & 0 & 0 & 0 & - & - & - \\
\hline Cladiella & 5 & 80 & 0 & 20 & 0 & - & - & - \\
\hline \multicolumn{9}{|l|}{ Asterospiculariidae } \\
\hline Asterospicularia & 12 & 58.3 & 25 & 16.7 & 2 & 100 & 0 & 0 \\
\hline \multicolumn{9}{|l|}{ Briareidae } \\
\hline Briareum & 12 & 66.7 & 8.3 & 25 & 0 & - & - & - \\
\hline \multicolumn{9}{|l|}{ Isidae } \\
\hline Isis & 19 & 78.9 & 5.3 & 15.8 & 0 & - & - & - \\
\hline \multicolumn{9}{|l|}{ Tubiporidae } \\
\hline Tubipora & 2 & 50 & 0 & 50 & 4 & 75 & 0 & 25 \\
\hline \multicolumn{9}{|l|}{ Clavularidae } \\
\hline Clavularia & 14 & 28.6 & 0 & 71.4 & 4 & 50 & 25 & 25 \\
\hline
\end{tabular}


and grew in small groups on the outer-shelf reefs. This species showed colony migration, whole-colony fission, stolon formation and high predation rates. Colonies had moved away from their tags within 6 mo, and therefore data from this unusual taxon were excluded from the above analysis.

Occasionally, single colonies of Sinularia with dimensions of up to $10 \times 15 \mathrm{~m}$ were found in the midand outer-shelf area. These large physiological individuals suggest either unusually high growth rates in a few species or in certain periods, and/or a great longevity. My observations on 3 of these colonies indicated that the edges of these colonies did not measurably extend within 3.5 yr. Hughes (1984) discussed the problems arising if one attempts to infer age from size in colonial animals. Shrinkage, fusion and fragmentation of colonies may effectively decouple age-size relationships. Assuming an annual survival rate of $98.6 \%$ (Table 3 ), the proportion of colonies remaining alive after $200 \mathrm{yr}$ is still $6 \%$. Even this figure may be an underestimate since survival tends to increase in colonial organisms with increasing size (Jackson 1985). With growth rates similar to those monitored here, and the colonies' inability to move away after fragmentation, it seems quite likely that the rare large colonies have occupied their space on the reef for hundreds of years.

Slow growth rates and great age in some alcyoniids have been suggested in 2 previous studies from other tropical regions. Benayahu (1982) mentioned an increase in diameter of a few millimetres per year in Sarcophyton glaucum from the northern Red Sea, and estimated the earliest reproductive age as older than 10 yr in females (Benayahu \& Loya 1986). Shinkarenko (1981) observed that the alcyoniids Sarcophyton trocheliophorum, Lobophytum crassum, L. pauciflorum and Cladiella pachyclados on the reef flats of Heron Island (southern Great Barrier Reef) were 'very slow growers'. In contrast, rapid growth and opportunistic characteristics are documented of the temperate species Alcyonium siderium (Sebens 1984).

Alcyoniidae did not recruit onto the settlement plates and to the quadrats around the tagged colonies, and soft coral recruitment in general was low compared to that of hard corals. Similar findings were reported in earlier studies from the Great Barrier Reef and the Red Sea (Stephenson \& Stephenson 1933, Benayahu \& Loya 1987). In these studies, Xeniidae were the first to recruit settlement plates and reef substrate, and only few single individuals of other taxa appeared after 3 to 12 yr. Unfortunately, the limited data available to date can only give first indications of low rates of successful sexual recruitment. The colonization and mortality rates on the photographed plots of natural reef substrate are probably indicative of processes on the reef, although settle- ment and mortality rates in the vicinity of the largest of the tagged colonies may be slightly influenced by allelopathic soft coral exudates (Maida 1995). All data suggest very low rates of successful larvae recruitment in tropical alcyoniids, and possibly many other alcyonaceans, compared to scleractinian corals.

Rates of predation on Sinularia and Sarcophyton are rather low. Predation rates on these genera were even lower $(<1 \%)$ on Heron Island than those found and documented here (Griffith 1993). Soft corals possess a variety of secondary metabolites, in particular diterpenes, which have antifouling and antipredatory properties, and can facilitate the competititive advantage of soft corals over hard corals (e.g. Alino et al. 1992). Toxin concentrations are variable within the genus Sinularia, and also within single species, and range from very high to a complete lack of feeding deterrence and toxicity (LaBarre et al. 1986). Sarcophyton spp. are known for their very high concentrations of toxic compounds (Coll et al. 1982). Nevertheless, several types of scars, such as small or large spots on the disk surface, disk lobes bitten off, or missing sectors of up to fist-size in the disk edge, indicate that a number of different predator species, including the snail Ovula ovum (Coll et al. 1989), feed on Sarcophyton.

The growth data for tagged colonies, colony turnover rates in the quadrats, and the previous life history studies on xeniids and nephtheids all present a fairly consistent pattern. Several xeniids and nephtheids may be classified as more 'fugitive' taxa, with high rates of asexual recruitment and mortality. Colony migration further increases their ability to immigrate onto open space or to overgrow live organisms, and some of these species may fulfil the role of pioneer colonizers of cleared substrate (Benayahu \& Loya 1986). The alcyoniids, on the other hand, are more long-lived, but slowly colonizing and slow growing taxa of the mid-and outer-shelf reefs

The range of habitats of Alcyoniidae is wider than that of other soft coral families, including near-shore environments, zones of high wave exposure, and areas of low irradiance at steep slopes, overhangs, and below $30 \mathrm{~m}$ depth (Fabricius \& Klumpp 1995). Fringing reefs, reefs close to the coast which experience considerable variability in salinity, nutrient and phytoplankton concentrations, and sediments (Furnas 1990, Baldwin 1992), are commonly characterized by a dominance of Alcyoniidae (Dinesen 1983, Alino et al. 1992). In contrast to other soft coral taxa, Alcyoniidae can persist despite the fluctuations in this environment, and may even be promoted by episodic nutrient enhancement. This wide distribution range and their generally high abundances indicate great persistence and possibly a broad physiological tolerance in Australian reef-inhabiting Alcyoniidae. 
Acknowledgements. I thank Mauro Maida for providing the settlement plates, and Terry Done for the loan of the stereophotography set-up. Phil Alderslade, Northern Territory Museum, Darwin, Australia, identified selected samples. A large number of volonteers helped in many days of field work. I gratefully acknowledge the support by David Klumpp. by an AIMS Fellowship, and a fellowship from the University of Munich. This is Contribution Number 761 of the Australian Institute of Marine Science.

\section{LITERATURE CITED}

Alino PM, Sammarco PW, Coll JC (1992) Competitive strategies in soft corals (Coelenterata, Octocorallia). IV. Environmentally induced reversals in competetive superiority. Mar Ecol Prog Ser 81:129-145

Baldwin C (1992) Impact of elevated nutrients in the Great Barrier Reef Great Barrier Reef. Marine Park Authority, Research Publication 20, Townsville

Bass DK, Davidson DB, Johnson DB, Miller-Smith BA, Mundy CN (1988) Broadscale surveys of crown-of-thorns starfish on the Great Barrier Reef, 1986 to 1987 Australian Institute of Marine Science, Townsville

Bayer FM (1957) Recent octocorals. In: Hedgpeth JW (ed) Treatise on manne ecology and palaeoecology, Vol 1 Geological Society of America, Memoir 67, Boulder, p $1105-1108$

Benayahu X (1982) Population dynamics of soft corals (Octocorallia, Alcyonacea) at the coral reefs of the Gulf of Eilat PhD thesis, Tel Aviv University (in Hebrew, English summary)

Benayahu Y, Loya Y (1981) Competition for space among coral-reef sessile organisms at Eilat, Red Sea. Bull mar Scl $31: 514-522$

Benayahu Y, Loya Y (1984) Life history studıes on the Red Sea soft coral Xenia macrospiculata Gohar, 1940. II. Planulae shedding and post larval development. Biol Bull 166: $44-53$

Benayahu Y, Loya Y (1986) Sexual reproduction of a soft coral: synchronous and brief annual spawning of Sarcophyton glaucum (Quoy and Gaimard, 1933). Biol Bull 170: $32-42$

Benayahu Y, Loya Y (1987) Long-term recruitment of soft corals (Octocorallia: Alcyonacea) on artificial substrata at Eilat (Red Sea). Mar Ecol Prog Ser 38:161-167

Coll JC, LaBarre S, Sammarco PW, Williams WT, Bakus CJ (1982) Chemical defences in soft corals (Coelenterata: Octocorallia) of the Great Barrier Reef: a study of comparatıve toxicities. Mar Ecol Prog Ser 8:271-278

Coll JC, Tapiolas DM, Bowden BF, Webb, L, Marsh H (1989) Transformation of soft coral (Coelenterata: Oclocorallia) terpens by Ovula ovum (Mollusca: Prosobranchia). Mar Biol 74:35-40

Dinesen ZD (1983) Patterns in the distribution of soft corals across the central Great Barrier Reef. Coral Reefs 1. $229-236$

Dinesen ZD (1985) Aspects of the life history of a stolon-bearing species of Efflatounaria (Octocorallia: Xeniidae). Proc 5th Int Symp Coral Reefs 6:89-94

Done TJ (1981) Photogrammetry ın coral ecology: a technique

This article was presented by D. M. Alongi (Senior Editorial Advisor), Townsville, Australia for the study of change in coral communities. In: Gomez E, Burkeland CE, Buddemeier RW, Johannes RE, Marsh JA Jr, Tsuda RT (eds) The reef and man. Proc 4th Int Coral Reef Symp. Univ Phillipines, Manila, p 315-320

Fabricius KE, Benayahu Y, Genin A (1995) Herbivory in asymbiotic soft corals. Science 268:90-92

Fabricius KE, Klumpp DW (1995) Widespread mixotrophy in reef-inhabiting soft corals: the influence of depth, and colony expansion and contraction on photosynthesis. Mar Ecol Prog Ser 125:195-204

Furnas M (1990) Nutrient status and trends in waters of the Great Barrier Reef Marine Park. In: Yellowlees D (ed) Land use patterns and nutrient loading of the Great Bartier Reef region. Workshop Proceedings, James Cook Unıversity, Townsville

Goldman AI (1992) Event charts: visualizing survival and other timed-events data. Am Stat 46:13-18

Griffith JK (1993) Impact of predation on soft corals (Octocorallia: Alcyonacea) on the Great Barrier Reef, Australia. Proc. Austr Mar Sci Ass, Melbourne, p 34

Hughes TP (1984) Population dynamics based on individual size rather than age: a general model with a reef coral example. Am Nat 123:778-795

Jackson JBC (1985) Distribution and ecology of clonal and aclonal benthic invertebrates. In: Jackson JBC, Buss LW, Cook RE (eds) Population biology and evolution of clonal organisms. Yale University Press, New Haven, p 297-355

LaBarre S, Coll JC (1982) Movement in soft corals: an interaction between Nephtea brassica (Coelenterata: Octocorallia) and A. hyaclnthus (Coelenterata: Scleractinia). Mar Biol 72:119-124

LaBarre S, Coll JC, Sammarco PW (1986) Competitive strategies of soft corals (Coelenterata: Octocorallia). III. Spacing and aggressive interactions between alcyonaceans. Mar Ecol Prog Ser 28:147-156

Maida M (1995) Directional allelopathic effects of the soft coral Sinularia flexibilus on scleractinian coral recruitment. Bull mar Sc1 56:303-311

Pearson RG (1981) Recovery and recolonization of coral reefs Mar Ecol Prog Ser 4:105-122

Sebens KP (1984) Water flow and coral colony size: interhabitat comparisons of the octocoral Alcyonium siderium. Proc Natl Acad Sci 81:5473-5477

Shinkarenko L (1981) The natural history of five species of octocorals (Alcyonacea), with special reference to reproduction, at Heron Island Reef, Great Barmer Reef. PhD thesis, University of Queensland, Brisbane

Stephenson TA, Stephenson A (1933) Growth and asexual reproduction in corals. Scient Rep Great Barrier Reef Expedition III 7:167-217

Tixier-Durivault A (1946) Les Alcyonaires du Museum, I. Famille des Alcyonidae. 3. Genre Sarcophyton. Bull Mus natn Hist nat, Paris (2) 18(4):348-354

Tursch B, Tursch A (1982) The soft coral community on a sheltered reef quadrat at Laing Island (Papua New Guinea) Mar Biol 68:321-332

Verseveldt J (1980) A revision of the genus Sinularia May (Octocorallia, Alcyonacea). Zool Verh, Leiden 179

Verseveldt J (1982) A revision of the genus Sarcophyton Lesson (Octocorallia, Alcyonacea). Zool Verh, Leiden 192

Manuscript first recelved: November 30, 1994

Revised version accepted: April 27, 1995 